\title{
Adipocyte insulin binding and insulin sensitivity in 'brittle' diabetes
}

\author{
R. Taylor, D.J.Husband, S. M. Marshall, W.M.G. Tunbridge ${ }^{1}$ and K. G. M. M. Alberti \\ Department of Clinical Biochemistry and Metabolic Medicine, Royal Victoria Infirmary, and \\ ${ }^{1}$ Department of Medicine, Newcastle General Hospital, Newcastle upon Tyne, UK
}

\begin{abstract}
Summary. Adipocyte insulin binding and insulin sensitivity to stimulation of lipogenesis were assessed in a group of extremely 'brittle' diabetic patients who were resistant to subcutaneous insulin therapy and had required frequent and prolonged hospital admission. These patients had significantly lower maximum adipocyte insulin binding (1.78 $\pm 0.18 \%)$ than age-, sex- and weight-matched stable diabetic control subjects $(2.57 \pm 0.36 \% ; p<0.05)$. Scatchard analysis suggested that the decreased binding was secondary to reduced receptor affinity with no change in receptor number. Adipocytes from the brittle subjects displayed resistance to insulin stimulation of lipogenesis compared with those from diabetic or normal
\end{abstract}

control groups (half-maximal stimulation at $34 \pm 4,15 \pm 3$ and $13 \pm 2 \mathrm{pmol} / 1$ respectively; $p<0.01$ between brittle and stable diabetic groups). In the one subject who was treated with intraperitoneal insulin, the changes in insulin binding and sensitivity were found to have reverted towards normal. The peripheral tissue abnormalities of brittle diabetes may exacerbate the clinical syndrome although the relationship of these changes to the primary cause of the syndrome is uncertain.

Key words: Brittle diabetes, adipocyte, insulin binding, insulin action, intraperitoneal insulin
The term 'brittle diabetes' has been applied in many different ways to states of unstable diabetic control. The term was originally used to describe a group of insulindependent diabetic patients who experienced frequent and inexplicable oscillations between hyperglycaemic ketosis and hypoglycaemia [1]. The definition was subsequently widened to include any diabetic whose life was disrupted by episodes of either hyperglycaemia or hypoglycaemia [2]. For the purpose of this study, the term 'brittle diabetes' is restricted to those subjects who were referred to this centre with extremely unstable diabetes, no cause for which could be identified, and who proved impossible to control on subcutaneous insulin despite intensive in-patient supervision. This definition, which has been used by others [3], serves to delineate those patients who present the most difficult problems of management. These patients all require high doses of insulin intramuscularly or intravenously, routes which achieve adequate plasma free insulin levels in such patients $[4,5]$. Resistance to the action of insulin at the tissue level therefore could explain the poor response of brittle diabetic patients to appropriate insulin therapy.

The present studies were performed in order to test the hypothesis that the abnormal response to insulin in brittle diabetes is a consequence of pathology at the lev- el of the insulin receptor or of the subsequent steps of insulin action. Adipose tissue was chosen for these studies, being metabolically important, capable of responding to insulin in vitro and readily accessible. The results of studies upon a group of brittle diabetic patients were compared with those of matched groups of stable insulin-dependent diabetic and non-diabetic subjects.

\section{Subjects and methods}

\section{Subjects}

Six insulin-dependent diabetic patients who had been referred to Newcastle upon Tyne from other centres throughout Great Britain with extremely unstable diabetes were studied. Prior to referral, the patients had suffered a mean of 19 episodes (range 5-35) of severe ketoacidosis and over the 6-month period immediately prior to referral had spent 80 days (range $42-120$ days) in hospital. No cause for the unpredictable tendency to ketoacidosis could be identified, and no patient could be controlled on subcutaneous insulin despite intensive supervision. The control group of seven stable insulin-dependent diabetic subjects was chosen to match the brittle group with respect to age, sex, body weight and duration of diabetes (Table 1). Only sub. jects with sub-optimal diabetic control were selected. The brittle group were receiving more than twice the daily insulin dose of the control group, three by intramuscular injection and three by intrave- 
Table 1. Clinical characteristics of the brittle diabetic, stable diabetic and normal groups

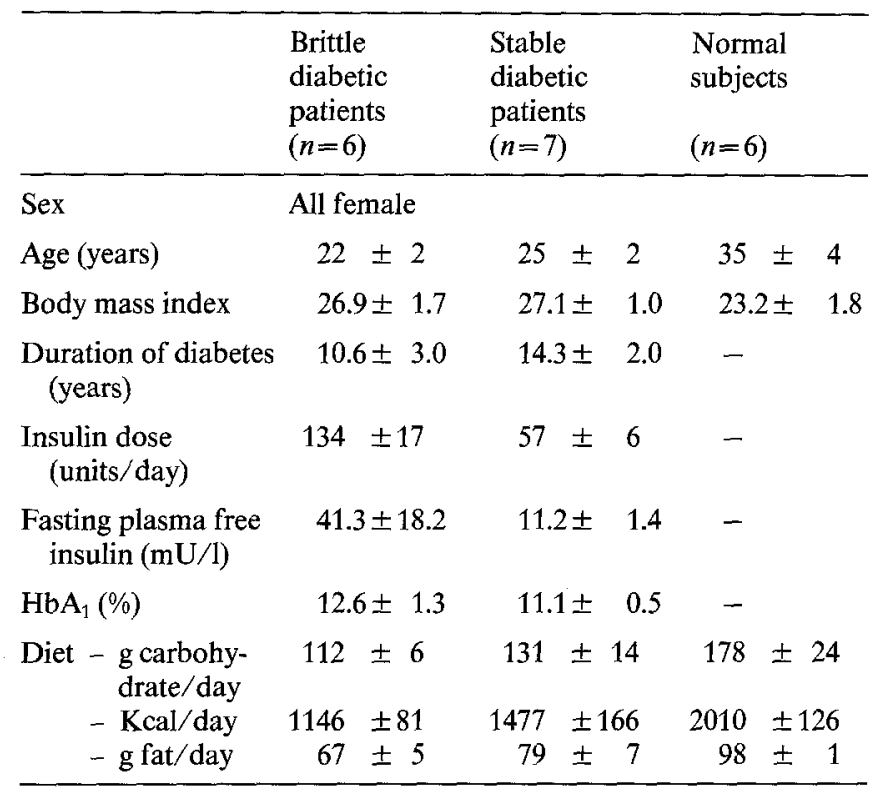

Data are expressed as mean \pm SEM.

There was no significant difference between the brittle and stable diabetic group apart from that in insulin dose $(p=0.001)$

nous infusion. All the control group were receiving subcutaneous insulin, one by continuous infusion and six by intermittent injection of short and intermediate acting insulins. Both diabetic groups were receiving carbohydrate-restricted diets. The brittle diabetic patients and one stable diabetic patient were studied as in-patients, and six of the stable diabetic subjects were studied as out-patients. One brittle diabetic patient, who was receiving intramuscular insulin at the time of the initial study $\left(\mathrm{HbA}_{1} 12.0 \%\right.$; insulin dose $1.64 \mathrm{U} \cdot \mathrm{kg}^{-1}$. day ${ }^{-1}$; fasting plasma free insulin $10.0 \mathrm{mU} / \mathrm{l}$ ), was subsequently treated with intraperitoneal insulin delivered by a Siemen's pump (Siemens, Erlangen, FRG). After 9 months, during which time diabetic control was stable $\left(\mathrm{HbA}_{1} 9.1 \%\right.$; insulin dose $0.57 \mathrm{U} \cdot \mathrm{kg}^{-1} \cdot$ day $^{-1}$; fasting free plasma insulin $20.4 \mathrm{mU} / \mathrm{l}$ ), a repeat fat biopsy was performed. Permission for the studies was given by the Newcastle upon Tyne Health Authority Ethical Committee and each patient gave informed consent.

\section{Sampling and preparation of adipocytes}

Subcutaneous adipose tissue $(2-3 \mathrm{~g})$ was obtained from the lateral gluteal region by open biopsy after cutaneous infiltration of $1 \%$ lignocaine. All biopsies were taken between 0800 and $0900 \mathrm{~h}$ after an overnight fast. The procedure was associated with minimal discomfort.

The adipocyte isolation procedure described by Pedersen et al. was used [6]. The subcutaneous tissue sample was conveyed to the laboratory in glucose-saline $(5 \mathrm{mmol} / 1$ glucose and $154 \mathrm{mmol} / 1$ $\mathrm{NaCl}$ ). The tissue was finely chopped using scissors and incubated with collagenase (collagenase $0.5 \mathrm{mg} / \mathrm{ml}$, human serum albumin $25 \mathrm{mg} / \mathrm{ml}$, glucose $5 \mathrm{mmol} / 1$ in a Hepes buffer, $\mathrm{pH} \mathrm{7.4)} \mathrm{in} \mathrm{a} \mathrm{shaking}$ water-bath $(120 \mathrm{cpm})$ for $90 \mathrm{~min}$ at $37^{\circ} \mathrm{C}$. The isolated adipocytes were then filtered through nylon mesh and washed extensively in a $5 \%$ human albumin/Hepes buffer, $\mathrm{pH} 7.4$. The mean cell diameter for each sample was determined using a micrometer eyepiece (Graticules, Tonbridge, Kent, UK) and the mean of the individual cell volumes and surface areas was calculated [6]. The adipocyte suspensions were adjusted to a lipocrit of $5 \%$ using a microhaematocrit centrifuge (Beckman Instruments, Palo Alto, USA). The cell number and total cell surface area per incubation tube were derived knowing the mean of the individual cell volumes, the lipocrit of the final suspension and the mean of the individual cell surface areas. The coefficient of variation of the cell sizing procedure was $2.0 \%$ and that of the lipocrit determination was $2.5 \%$.

\section{Adipocyte insulin binding}

Insulin binding to adipocytes was measured by incubating $300 \mu \mathrm{lali}$ quots of cell suspension with $100 \mu \mathrm{l} \mathrm{A}_{14}$ labelled monoiodoinsulin [7] (final concentration 4-6 pmol/l) and $100 \mu \mathrm{l}$ buffer or unlabelled insulin (final concentration $120-21,000 \mathrm{pmol} / 1$ ) in duplicate at $37^{\circ} \mathrm{C}$ for $60 \mathrm{~min}$ in a Hepes buffer (mmol/1: $\mathrm{Na}^{+}, 135 ; \mathrm{K}^{+}, 4.8 ; \mathrm{Mg}^{++}, 1.7$; $\mathrm{Ca}^{++}, 2.5 ; \mathrm{H}_{2} \mathrm{PO}_{4}{ }^{-}, 0.2 ; \mathrm{HPO}_{4}{ }^{2-}, 1.0 ;$ Hepes 10 , and glucose $1.0 \mathrm{mmol} / 1$, with human serum albumin $50 \mathrm{mg} / \mathrm{ml}, \mathrm{pH} 7.4$ ). The binding was stopped by adding $10 \mathrm{ml}$ chilled $154 \mathrm{mmol} / \mathrm{I} \mathrm{NaCl}$. Silicone oil $(1 \mathrm{ml}$, density $0.97 \mathrm{~g} / \mathrm{ml})$ was layered on the surface and the tubes were spun at $1,000 \mathrm{~g}$ for $3 \mathrm{~min}$. The cell pellet was harvested using a pipe cleaner as described by Gliemann and Sonne [8]. Specific binding was calculated by subtracting the binding observed in the presence of unlabelled insulin $(10 \mu \mathrm{mol} / \mathrm{l})$ from the total binding for each insulin concentration. The non-specific binding averaged $1.5 \pm 0.2 \%$ of cell bound insulin at a tracer concentration of $16 \mathrm{pmol} / 1$. The intraassay coefficient of variation of specific binding at a tracer concentration of $4 \mathrm{pmol} / 1$ was $2.3 \%$. Binding was expressed as percentage specific binding per $10 \mathrm{~cm}^{2}$ adipocyte membrane [9].

\section{Insulin degradation}

Degradation of $\mathrm{A}_{14}$ labelled monoiodoinsulin under the conditions described for insulin binding was assessed by addition of trichloracetic acid $(12 \%)$ to an aliquot of the incubation medium [8]. The precipitate was separated by centrifugation at $2,000 \mathrm{~g}$ for $3 \mathrm{~min}$ and the rato of ${ }^{125} \mathrm{I}$ in the supernate to ${ }^{125} \mathrm{I}$ in the precipitate was determined. Degradation was assessed in the presence of tracer insulin $(16 \mathrm{pmol} / \mathrm{l})$ alone and in the presence of tracer insulin together with an excess of cold insulin $(10 \mu \mathrm{mol} / \mathrm{l})$.

\section{Insulin stimulation of lipogenesis}

Triplicate $200 \mu \mathrm{l}$ aliquots of adipocytes in a glucose-free Hepes buffer (composition as above apart from absence of glucose) were pre-incubated at $37^{\circ} \mathrm{C}$ for $45 \mathrm{~min}$ with or without increasing amounts of insulin. Glucose $\left(0.4 \mu \mathrm{Ci} \mathrm{D}-\left(\mathrm{U}^{14} \mathrm{C}\right)\right.$, final concentration $\left.6 \mu \mathrm{mol} / 1\right)$, was added and the incubation was continued without shaking for $90 \mathrm{~min}$. The reaction was stopped by adding $1 \mathrm{~mol} / 1 \mathrm{H}_{2} \mathrm{SO}_{4}(200 \mu \mathrm{l})$ and the tubes were allowed to stand for $60 \mathrm{~min}$ before the total lipid fraction was separated using the procedure of Dole and Meinertz [10]. The amount of $\mathrm{D}-\left(\mathrm{U}^{14} \mathrm{C}\right)$ glucose incorporated into lipid for each triplicate set of tubes was calculated and expressed as pmol/1 glucose incorporated per $90 \mathrm{~min}$ per $10 \mathrm{~cm}^{2}$ adipocyte membrane. At the trace glucose concentration used, glucose transport is probably the rate-limiting step of lipogenesis [9].

\section{Chemicals}

Human serum albumin ( $>99 \%$ electrophoretically pure) was obtained from Hoechst, Hounslow, Middlesex, UK. Collagenase from Clostridium histolyticum (Batch no. 504-22) was obtained from P-L Biochemicals, Milwaukee, Wisconsin, USA. Crystalline porcine insulin and mono ${ }^{125} \mathrm{I}-\left(\mathrm{A}_{14} \mathrm{Tyr}\right)$ insulin were supplied by Novo Industries, Copenhagen, Denmark. U-( $\left.{ }^{14} \mathrm{C}\right)-\mathrm{D}$-glucose (sp. act. $\left.270 \mathrm{Ci} / \mathrm{mol}\right)$ was purchased from Amersham International, Bucks, UK

\section{Statistical analyses}

Statistical analyses were carried out using the Mann-Whitney $U$ test and Spearman rank correlation coefficient. Results are expressed as mean \pm SEM. 


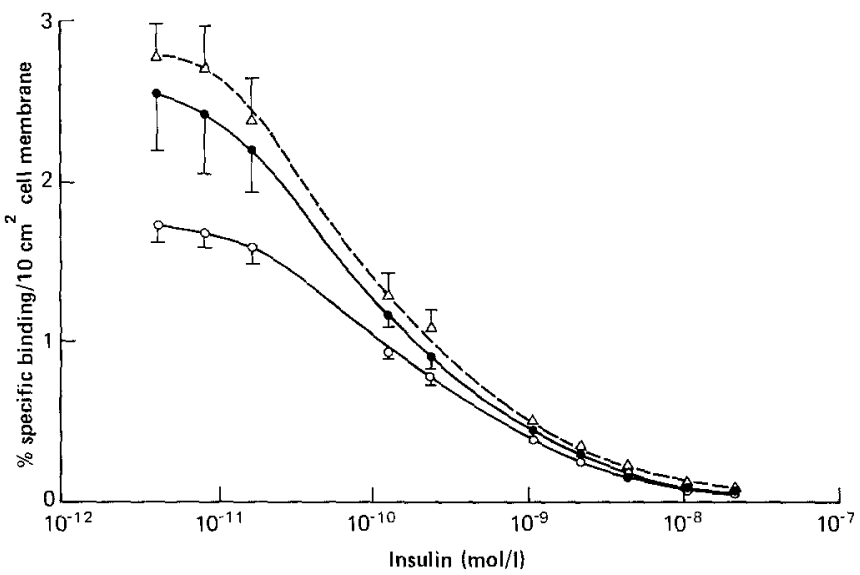

Fig. 1. Specific insulin binding to adipocytes from brittle diabetic patients $(\mathrm{O}-\mathrm{O})$, stable diabetic patients $(-\infty)$ and normal subjects $(\triangle \cdots \triangle)$. Mean \pm SEM

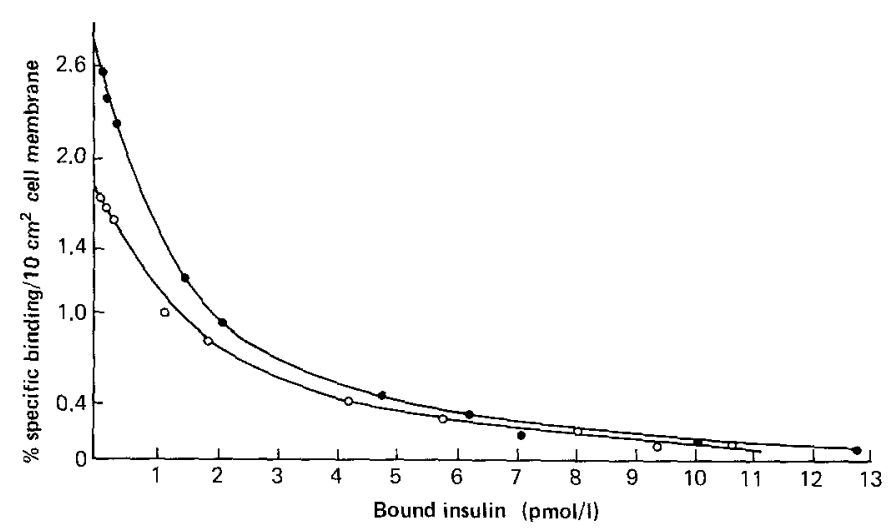

Fig. 2. Scatchard plots of adipocyte insulin binding for the brittle $(\mathrm{O}-\mathrm{O})$ and stable $(-)$ diabetic groups. SEM bars have been omitted for clarity, but measure of vertical scatter of points may be read from Figure 1

\section{Results}

\section{Adipocyte insulin binding}

The binding displacement curves are shown in Figure 1. Insulin binding at tracer insulin concentrations was significantly reduced in the brittle group $(1.78 \pm 0.18 \%)$ compared with the stable diabetic group $(2.57 \pm 0.36 \%$; $p<0.05$ ), who themselves were not significantly different from control subjects. The difference in binding between brittle and stable diabetic patients was significant at all insulin concentrations up to $120 \mathrm{pmol} / 1$. Halfmaximal displacement of tracer insulin was observed at $206 \pm 42$ for the brittle group and $122 \pm 13 \mathrm{pmol} / 1$ for the stable group $(p=0.069)$. This suggestion of reduced receptor affinity in the brittle group was borne out by Scatchard analysis (Fig. 2). The slope of the high affinity portion of the Scatchard plot for the brittle group was found to be reduced, but the receptor number, as assessed from the $\mathrm{x}$ axis intercepts, was similar in the two groups. Adipocyte insulin binding data for the normal control group are summarized in Table 2.
Table 2. Adipocyte insulin binding, insulin sensitivity and insulin degradation in the non-diabetic group, and in the stable and brittle diabetic groups

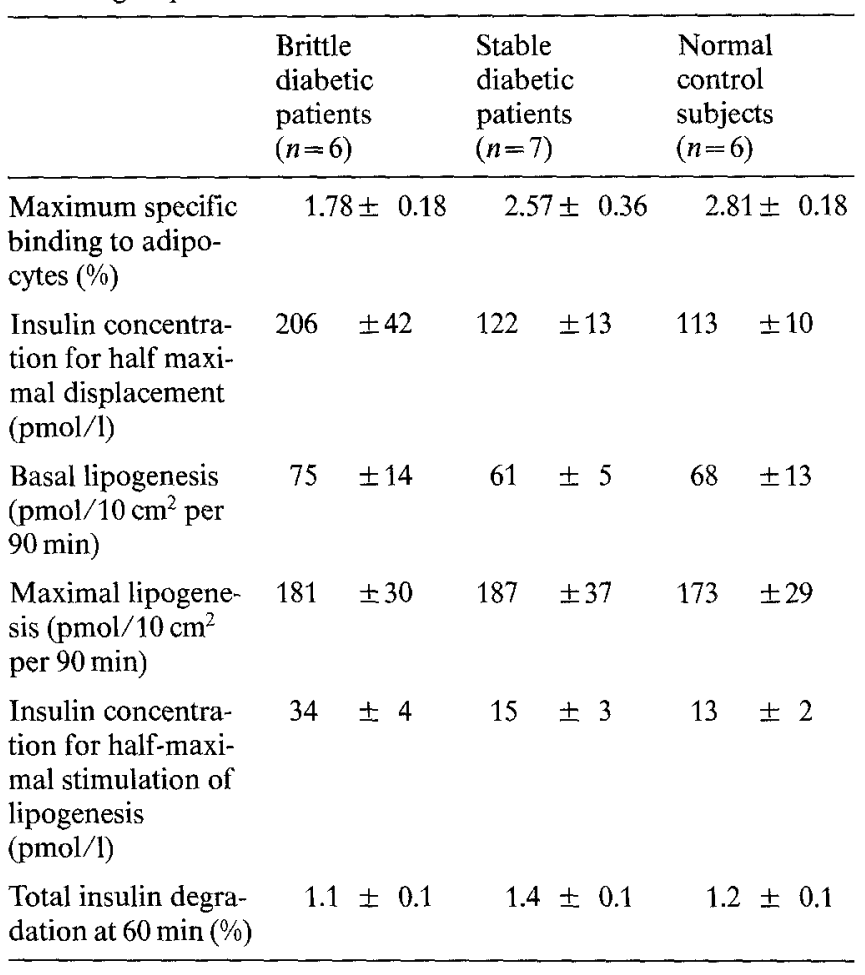

Results expressed as mean \pm SEM

\section{Adipocyte insulin degradation}

Total insulin degradation was similar in the presence of cells of the brittle, stable diabetic and normal groups $(1.14 \pm 0.04 \%, 1.36 \pm 0.12 \%$ and $1.21 \pm 0.11 \%$, respectively at $60 \mathrm{~min}$ and $2.41 \pm 0.17 \%, 2.66 \pm 0.21 \%$ and $2.42 \pm 0.10 \%$, respectively at $120 \mathrm{~min}$; Fig. 3 ). Tracer insulin degradation in the presence of cold insulin $(10 \mu \mathrm{mol} / 1)$ did not increase markedly between 60 and $120 \mathrm{~min}$, whereas the increase in tracer insulin degradation in the absence of cold insulin increased linearly with time.

\section{Adipocyte insulin sensitivity}

Basal and maximal rates of lipogenesis were similar in the two diabetic groups $(75 \pm 14,181 \pm 30$ and $61 \pm 5$, $187 \pm 37 \mathrm{pmol} / 1$ per $10 \mathrm{~cm}^{2}$ per $90 \mathrm{~min}$ for brittle and stable groups, respectively). The percentage stimulation of lipogenesis is shown in Figure 4. The insulin concentration required to achieve half-maximal stimulation was $34 \pm 4 \mathrm{pmol} / 1$ for the brittle group and $14 \pm$ $3 \mathrm{pmol} / 1$ for the stable group $(p<0.01)$. The data for the non-diabetic group are given in Table 2.

\section{Relationship between adipocyte insulin binding and insulin sensitivity}

There was a negative correlation between maximum specific binding to adipocytes and the insulin concentration required to achieve half-maximal stimulation of 


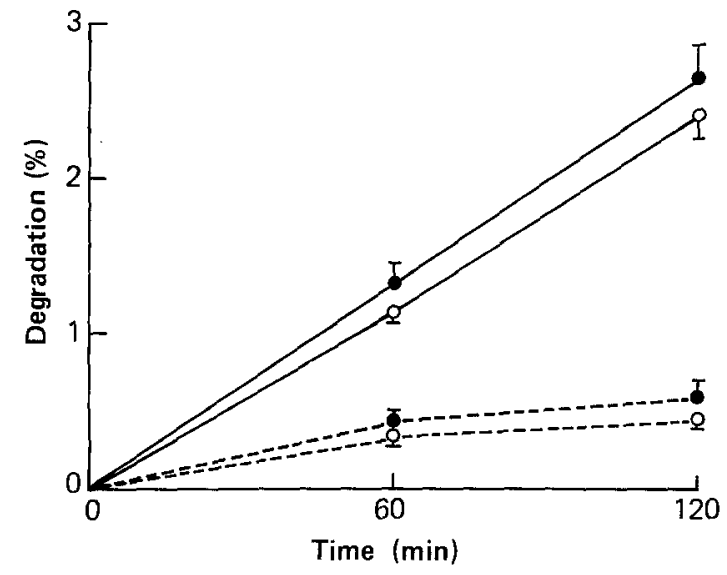

Fig.3. Degradation of tracer insulin in the presence of adipocytes from brittle diabetic patients $\left(\mathrm{O}_{-} \mathrm{O}\right)$ and stable diabetic patients (- ) : - in the presence of tracer insulin alone; -..-- in the presence of $10 \mu \mathrm{mol} / 1$ unlabelled insulin

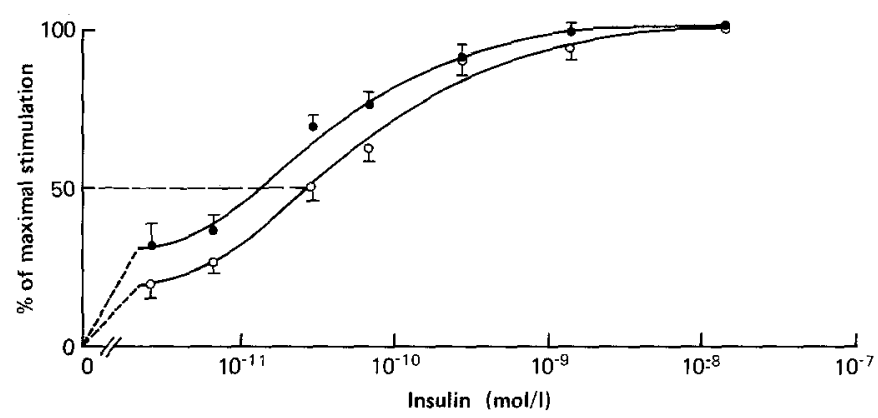

Fig. 4. Percentage stimulation of lipogenesis in adipocytes from brittle $(\mathrm{O}-\mathrm{O})$ and stable $(-)$ ) diabetic subjects. Dotted line indicates $50 \%$ stimulation

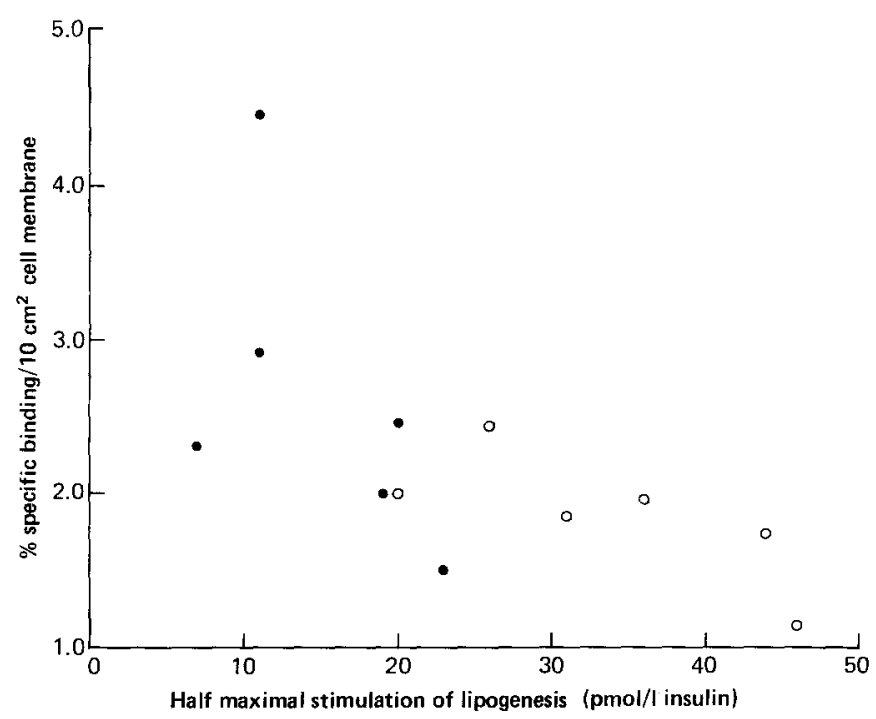

Fig.5. Relationship between maximum specific insulin binding and insulin concentration required for half-maximal stimulation of lipogenesis in adipocytes from brittle $(O)$ and stable ( $)$ diabetic patients $\left(\mathrm{R}_{\mathrm{s}}=0.78 ; p<0.01\right)$
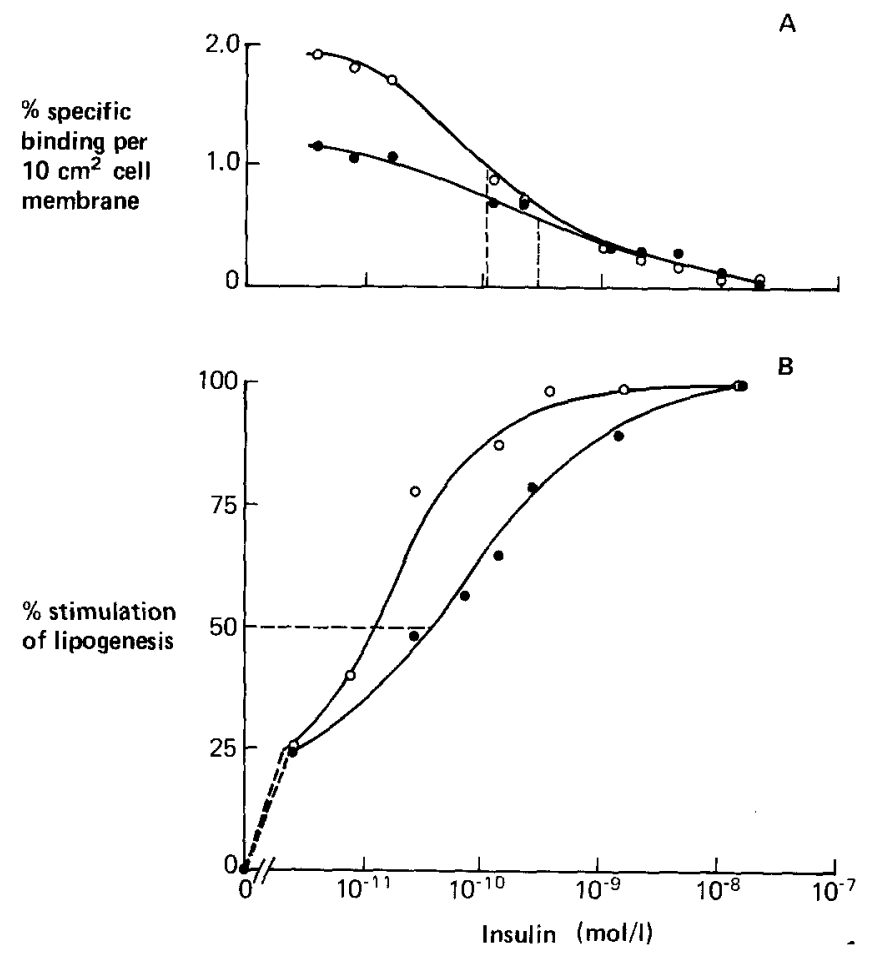

Fig. 6 $\mathrm{A}$ and B. Specific insulin binding $(\mathbf{A})$ and percentage stimulation of lipogenesis $(\mathbf{B})$ in a brittle diabetic during intramuscular insulin therapy $(-)$ ) and after 9 months of intraperitoneal insulin administration $(\mathrm{O}-\mathrm{O}$ ). Dotted lines represent half-maximal displacement of insulin (A) and 50\% maximal stimulation (B)

lipogenesis (Fig. 5) for all diabetic subjects $\left(\mathrm{R}_{s}=0.78\right.$, $p<0.01)$ and for the brittle diabetic patients alone $\left(\mathrm{R}_{\mathrm{S}}=0.89, p<0.05\right)$.

\section{Effects of achieving stable control}

In the patient who was studied twice, maximum specific insulin binding was $1.15 \%$ during treatment with intramuscular insulin $\left(1.64 \mathrm{U} \cdot \mathrm{kg}^{-1} \cdot \mathrm{day}^{-1}\right)$, and this rose to $1.90 \%$ during treatment with intraperitoneal insulin $\left(0.57 \mathrm{U} \cdot \mathrm{kg}^{-1} \cdot \mathrm{day}^{-1}\right)$. The rise in binding was accompanied by an appreciable decrease in the insulin concentration required for half-maximal displacement of tracer (Fig. 6). This increase in receptor affinity was accompanied by an increase in insulin sensitivity in vitro, the insulin concentration required to achieve halfmaximal stimulation after intraperitoneal insulin being almost identical to that for the stable diabetic group (Fig.4).

\section{Discussion}

The results presented here demonstrate that this group of brittle diabetic patients have normal receptor number, but reduced adipocyte insulin receptor affinity and that this reduction in affinity is reflected in resistance to insulin stimulation of lipogenesis in vitro. The insulin 
dosage in the brittle group was more than double that of the control group and the possibility of receptor downregulation by insulin must be considered. There was, however, no relationship between insulin dose and maximum insulin binding within either group. Similarly, there was no relationship between insulin dose and half-maximal stimulation of lipogenesis. Fasting plasma free insulin levels were markedly higher in those brittle diabetic patients receiving insulin by intravenous infusion $(74 \pm 24 \mathrm{mU} / 1)$ rather than by intermittent intramuscular injection $(8.7 \pm 3.5 \mathrm{mU} / \mathrm{l})$, but this bore no relationship to the extent of the reduction in insulin binding or insulin sensitivity. Furthermore, the mean fasting plasma free insulin level was higher in the control group than in the brittle subjects receiving intramuscular insulin. Dietary factors, especially fat intake, have been shown to have an important influence upon cellular insulin binding [11, 12]. The mean fat intake of the brittle diabetic group was only slightly lower than that of the stable diabetic patients and would not have been expected to affect insulin binding. The two diabetic groups were well matched with respect to age and body mass index.

Previous studies in vivo and in vitro have suggested that short-term down-regulation of insulin receptors can be mediated by reduction in cell surface receptor number $[13,14]$. Studies of adipocyte insulin binding in various clinical states of insulin resistance have also suggested that reduction in adipocyte insulin binding is most often a result of reduced receptor number [15-17]. Short-term changes in insulin receptor affinity have been recorded after acute changes in food intake [18-20], after hydrocortisone [21] and after growth hormone administration [22]. Examples of chronic reduction in receptor affinity are rare, having been demonstrated during high fat diets [23], in one study of obese subjects [24] and during glucocorticoid administration in rats [25]. The reduction of receptor affinity observed in the group of brittle diabetic patients is therefore of particular interest. The cause of this change in receptor affinity is uncertain. No abnormalities in serum glucagon, growth hormone, prolactin or catecholamines have been observed in brittle diabetes and although morning cortisol levels have been noted to be somewhat elevated, mean 24-h serum cortisol levels in the same subjects were unremarkable (M. Massi-Benedetti et al., unpublished observations). Serum non-esterified fatty acid and total ketone body levels were observed to be variable, but not consistantly high [28]. The syndrome of brittle diabetes is intimately related to the administration of extremely variable insulin doses over a long period of time. As insulin itself appears to be a major factor regulating the insulin receptor, the observation of an unusual adipocyte insulin receptor status is perhaps not surprising. The adipocyte insulin binding in the stable diabetic group was not significantly different from that of an age- and sex-matched group of normal subjects. This is at variance with Pedersen and Hjollund's find- ing of reduced adipocyte insulin binding in a group of stable insulin-dependent diabetic patients [15]. In the same group of subjects, Pedersen and Hjollund observed similar rates of initial glucose transport and identical insulin sensitivity, results very similar to those of the present study. It is possible that the discrepancy in insulin binding results is a consequence of the selection criteria used in the two studies, poorly controlled stable diabetic subjects being specifically chosen as controls for the brittle diabetic subjects in the present study. Relative hypoinsulinaemia in these subjects could account for the differing results, and, indeed, the mean fasting plasma free insulin was only $50 \%$ of that reported by Pedersen and Hjollund [15]. Other possible reasons include differences in age, body weight and dietary factors, the stable diabetic group having a lower fat intake. The differences in dietary intake are small compared with those shown to be able to influence insulin binding $[11,12]$.

It has been suggested that increased degradation of insulin in the subcutaneous tissues may account for the poor response to subcutaneous insulin characteristic of brittle diabetic patients $[26$, G.V.Gill, unpublished observations]. The studies on insulin degradation presented here demonstrate that the adipocytes themselves are not responsible for any such abnormal degradation, although other subcutaneous components could be involved in insulin degradation. The similarity in insulin degradation in the presence of adipocytes from each of the groups also eliminates this as a possible cause of the observed low insulin binding to the cells of the brittle diabetic patients.

Although intramuscular insulin is sometimes effective in achieving adequate plasma free insulin levels and reasonable metabolic control in the short term $[3,4]$, this is often not so and long-term intravenous insulin may be required [26]. Both of these routes induce hyperinsulinaemia in the peripheral circulation, a factor which can be avoided at least in part by peritoneal delivery of insulin [27-29]. In the brittle patient restudied after a 9-month period of satisfactory metabolic control on intraperitoneal insulin therapy, both adipocyte insulin binding and insulin sensitivity reverted towards the mean of the stable diabetic group. The reversal of the abnormalities characteristic of brittle diabetes brought about by this change in route of administration and dose of insulin indicates that the reduced receptor affinity and adipocyte insulin resistance are unlikely to be primary changes. Once present, however, these changes are likely to exacerbate the clinical problems.

In conclusion, reduced adipocyte insulin receptor affinity and reduced adipocyte insulin sensitivity have been observed in brittle diabetes. These abnormalities were observed during treatment with high doses of insulin administered intramuscularly or intravenously. The reversal of the abnormalities during treatment with intraperitoneal insulin in one patient suggests that insulin receptor changes may not be the primary cause of the 
syndrome, although no direct relationship of the tissue abnormalities to either insulin dose or plasma free insulin levels could be established.

Acknowledgements. We are grateful to our patients and normal volunteers for participating in the study, to the nursing staff of Ward 15, Freeman Hospital, for their cooperation and to Miss M. York for expert dietary assessments. Mr. I. Hanning performed the plasma free insulin assays. The $\mathrm{A}_{14}$ labelled monoiodoinsulin and crystalline porcine insulin were gifts from Novo. The work was supported by Medical Research Council Project Grant No. G82207505B, by the British Diabetic Association and by the Newcastle Regional Health Authority Research Committee. RT holds a Medical Research Council Training Fellowship.

\section{References}

1. Woodyatt RT (1937) Diabetes mellitus. In: Cecil R (ed) Textbook of medicine, 4 th edn. W. B. Saunders, Philadelphia, pp 620-634

2. Tattersall R (1977) Brittle diabetes. Clin Endocrinol Metab 6: 403-419

3. Pickup JC, Williams G, Johns P, Keen H (1983) Clinical features of brittle diabetic patients unresponsive to optimised subcutaneous therapy (continuous subcutaneous insulin infusion). Diabetic Care 6: 279-284

4. Pickup JC, Home PD, Bilous RW, Keen H, Alberti KGMM (1981) Management of severely brittle diabetes by continuous subcutaneous and intramuscular insulin infusions: evidence for a defect in subcutaneous insulin absorption. Br Med J 292:347-350

5. Home PD, Massi-Benedetti M, Gill GV, Capaldo B, Shepherd GAA, Alberti KGMM (1982) Impaired subcutaneous absorption of insulin in "brittle" diabetes. Acta Endocrinol 101: 414 420

6. Pedersen O, Hjollund E, Beck-Nielsen H, Lindskov HO, Sonne O, Gliemann J (1981) Insulin receptor and receptor mediated insulin degradation in human adipocytes. Diabetologia 20:636-641

7. Jorgensen KH, Larsen UD (1980) Homogenous mono ${ }^{125} \mathrm{I}$ insulins. Preparation and characterisation of mono ${ }^{125} \mathrm{I}\left(\mathrm{Tyr} \mathrm{A}_{14}\right)$ and mono ${ }^{125} \mathrm{I}\left(\mathrm{Tyr} \mathrm{A}_{19}\right.$ ) insulin. Diabetologia 19: 546-554

8. Gliemann J, Sonne O (1978) Binding and receptor mediated degradation of insulin in adipocytes. J Biol Chem 253: 7857-7863

9. Pedersen O, Hjollund E, Lindskov HO (1982) Insulin binding to fat and blood cells and insulin action in fat cells from young healthy males and females. Am J Physiol 243: E158-167

10. Dole VP, Meinertz H (1960) Microdetermination of long chain fatty acids in plasma tissues. J Biol Chem 235:2575-2599

11. Hjollund E, Pedersen O, Richelsen B, Beck-Nielsen H, Sorensen NS (1983) Increased insulin binding to adipocytes and monocytes and increased insulin sensitivity of glucose transport and metabolism in adipocytes from non-insulin-dependent diabetics after a low-fat/high-starch/high fiber diet. Metablism 32: 1067-1075

12. Ward GM, Simpson RW, Simpson HCR, Naylor BA, Mann J, Turner RC (1982) Insulin receptor binding increased by high carbohydrate low fat diet in non-insulin-dependent diabetics. Eur J Clin Invest 12: 93-96

13. Marshall S, Olefsky JM (1980) Effects of insulin internalisation, insulin binding, glucose transport and insulin degradation by isolated rat adipocytes. $\mathrm{J}$ Clin Invest 66: 763-772

14. Pezzino V, Vigneri R, Pliam NB, Goldfine ID (1980) Rapid regula- tion of plasma membrane insulin receptors. Diabetologia 19: 211-215

15. Pedersen O, Hjollund E (1982) Insulin receptors on fat and blood cells and insulin action in fat cells from patients with insulin-dependent diabetes. Diabetes 31: 706-715

16. Olefsky JM (1976) Decreased insulin binding to adipocytes and circulating monocytes from obese subjects. J Clin Invest 57: $1165-72$

17. Olefsky JM, Kolterman OG, Scarlett JA (1982) Insulin action and resistance in obesity and noninsulin dependent type II diabetes mellitus. Am J Physiol 243: E15-30

18. Livingston JM, Moxley RT III (1982) Glucose ingestion mediates a rapid increase in the insulin responsiveness of rat adipocytes. Endocrinology 111: 1749-1751

19. Bar RS, Gordon P, Roth J, Kahn CR, DeMeyts P (1976) Fluctuations in the affinity and concentration of insulin receptors on circulating monocytes of obese patients. Effects of starvation, refeeding and dieting. J Clin Invest 58: 1123-1135

20. Beck-Nielsen H, Pedersen O (1978) Diurnal variation in insulin binding to human monocytes. J Clin Endo Metab 47: 385-390

21. Yasuda K, Kitabchi AE (1980) Decreased insulin binding of human erythrocytes after dexamethasone or prednisone ingestion. Diabetes 29: 811-814

22. Bratusch-Marrain PR, Smith D, DeFronzo RA (1980) The effect of growth hormone on glucose metabolism and insulin secretion in man. J Clin Endocrinol Metab 55: 973-982

23. Beck-Nielsen H, Pedersen O, Schwartz Sorensen N (1978) Effects of diet on cellular insulin binding and the insulin sensitivity in young healthy subjects. Diabetologia 15: 289-296

24. Pedersen O, Hjollund E, Sorensen NS (1981) Insulin receptor binding and insulin action in human fat cells. Effects of obesity and fasting. Metabolism 31: 884-895

25. Kahn CR, Goldfine ID, Neville DM, DeMeyts P (1978) Alterations in insulin binding induced by changes in vivo in the levels of glucocorticoids and growth hormone. Endocrinology 103: 1054-1066

26. Berger M, Halban PA, Girardier L, Seydoux J, Offord RE, Renold $\mathrm{AE}$ (1979) Kinetics of subcutaneously injected insulin: evidence for degradation at the injection site. Diabetologia 17:97-99

27. Pozza G, Spotti D, Micossi P, Cristallo M, Melandri M, Piatti PM, Monti LD, Pontiroli AE (1983) Long-term continuous intraperitoneal insulin treatment in brittle diabetes. $\mathrm{Br}$ Med J 286:255-256

28. Schade DS, Eaton RP, Friedman NM, Spencer WJ (1980) Normalisation of plasma insulin profiles with intraperitoneal insulin infusion in diabetic man. Diabetologia 19:35-39

29. Husband DJ, Marshall SM, Walford S, Hanning I, Wright PD, A1berti KGMM (1984) Continuous intra-peritoneal insulin infusion in the management of severely brittle diabetes - a metabolic and clinical comparison with intravenous infusion. Diabetic Med (in press)

Received: 26 January 1984

and in revised form: 30 July 1984

Dr. R. Taylor

Department of Clinical Biochemistry and Metabolic Medicine

Royal Victoria Infirmary

Newcastle upon Tyne NE1 4LP

UK 